or some of, the igneous sills are contemporaneous with those dated elsewhere in North Greenland (Henriksen \& Jepsen, 1970) then some sediments, including the Rensselaer Bay Sandstone, must be pre-Palaeozoic. On the other hand, if the Rensselaer Bay Sandstone in Canada, and thus in Greenland is of Cambrian age (Kerr, 1967), correlation between Inglefield Land and the area south of Dodge Gletscher suggests that at least $1 \mathrm{~km}$ of Palaeozoic deposits exists in Prudhoe Land and probably over $2 \mathrm{~km}$ in the entire Thule Basin.

\title{
References
}

Berthelsen, A. \& Noe-Nygaard, A. 1965: The Precambrian of Greenland. In Rankama, K. (editor): The Precambrian, 2, 113-262. London: Interscience Publishers.

Cowie, J. W. 1961: Contributions to the geology of North Greenland. Meddr Gronland 164, $3,47 \mathrm{pp}$.

Henriksen, N. \& Jepsen, H. F. 1970: K/Ar age determination on dolerites from southern Peary Land, North Greenland. Rapp. Gronlands geol. Unders. 28, 55-58.

Kerr, J. W. 1967: Stratigraphy of central and eastern Ellesmere Island, Arctic Canada. Part 1. Proterozoic and Cambrian. Pap. geol. Surv. Can. 67-27, pt. 1, 63 pp.

Koch, L. 1926: A new fault zone in Northwest Greenland. Am. J. Sci., 5th Ser. 12, 301-310.

Koch, L. 1929: Stratigraphy of Greenland. Meddr Grønland 73, 2 Afd. 2, 205-320.

Koch, L. 1933: The geology of Inglefield Land. Meddr Gronland 73, 1 Afd. 2, 38 pp.

Larsen, O. \& Møller, J. 1968: K/Ar age determinations from western Greenland. I. Reconnaissance programme. Rapp. Gronlands geol. Unders. 15, 82-86.

Schei, P. 1903: Summary of geological results. The Second Norwegian Polar Expedition in the 'Fram'. Geogr. J. 22, 56-65.

Troelsen, J. C. 1950: Contributions to the geology of Northwest Greenland, Ellesmere Island, and Axel Heiberg Island. Meddr Grønland 149, 7, 86 pp.

\section{GEOLOGICAL AND GEOPHYSICAL WORK IN CENTRAL WEST GREENLAND}

\section{Gilroy Henderson}

During the summer a new programme for the detailed geological and geophysical investigation of the Cretaceous-Tertiary sedimentary and volcanic rocks of central West Greenland was embarked on. This programme follows on work already undertaken in this area since 1938 (see Rosenkrantz \& Pulvertaft, 1969; Henderson, 1969b; Rosenkrantz, 1970). Extensive areas of thick sediments and an extension of the volcanic rocks have been discovered in recent years offshore from central West Greenland. A review of the published information is given by Henderson (in press). It thus became clear that the onshore area is a key area and that a 
better understanding of the exposed rocks would contribute greatly to the interpretation of the offshore geology.

Three main groups participated in the expedition: a field mapping group, a geophysical group and a drilling group. A team of 16 people comprising five geologists, a geophysicist, three technicians and seven assistants worked in the area during the summer. The expedition was supported by the GGU ship "K.J.V. Steenstrup", with A. Viðstein as skipper.

This report gives a preliminary account of the work of the expedition. A more detailed account, with contributions by the various participants, will be prepared for publication in 1972.

\section{Field mapping group}

A party led by A. K. Pedersen (Univ. of Copenhagen) continued the detailed field investigation of northern Disko, the work being concentrated in a zone of about 40 $\mathrm{km}$ along the north coast. This work was a continuation of that undertaken in 1968 (Pedersen, 1969). Investigation of the base of the volcanic sequence showed that these rocks were laid down on an irregular land surface dipping from east to west. Seven subdivisions of the lower lava formation, which overlies the basal pillow breccias, were recognized and mapped. These include the Asuk-Manitdlat suite of telluric-iron-bearing lavas and related bronzite basalts. The study of these units showed that subsidence of the area to the east relative to that in the west continued from the start of the volcanism at least until the eruption of the lower part of the upper lava formation. The transition zone between the lower and upper formations and the upper formation itself were also studied. A number of dykes were investigated and sampled.

A party led by $\mathrm{N}$. Hald (Univ. of Copenhagen) undertook detailed investigations in the north-western part of Nûgssuaq. The work was an extension northwards of work undertaken on Hareøen and part of the coast of Nûgssuaq opposite Hareøen in 1970 (Hald, 1971). The main objects were to sample in detail the upper, tholeiitic formation and to investigate the complex pattern of block faulting already known to exist in this part of Nûgssuaq. Interbasaltic sedimentary layers and layers of tuff are present and provide very useful markers in elucidating the structure of this area. One of these tuff layers was followed for $10 \mathrm{~km}$. Mapping of the areas containing sedimentary horizons will make it possible to evaluate the magnitude of a possible angular unconformity between the basaltic layers above and below the sedimentary layers.

Parts of the south-west and west coasts of Ubekendt Ejland were investigated by a party led by D. B. Clarke (Dalhousie Univ.). The object was to undertake detailed mapping and sampling of the basalts for a petrogenetic study, and the work was planned in the light of work undertaken earlier on Svartenhuk by Pulvertaft and Clarke (1966). This island has been the subject of considerable research by expeditions from the University of St. Andrews (Drever, 1958), and an 
expedition led by Professor H. I. Drever was also based on the island during the summer. Clarke collaborated with J. G. Larsen, who was attached to this expedition. A minor accident disabled Clarke for the last part of the season, and collection of samples was continued by his assistant, C. Wewer.

Typical West Greenland feldspar-porphyritic basalts, which characterise the upper lava formation elsewhere in West Greenland, were not seen in the parts of Ubekendt Ejland investigated. Most of the feldspar-porphyritic basalts are unique in character. Despite the abundance of xenoliths of both ultrabasic and Precambrian basement material in some of the flows and dykes, no sedimentary xenoliths were seen.

In the middle of the summer a GGU consultant, N. B. H. Stevens of Olexcon International, paid a one-week visit to the area. During this period samples were collected for isotopic age determination from the $444 \mathrm{~km}$ long olivine dolerite dyke that has been traced from north-east of Jakobshavn to north of Upernavik. The importance of this dyke in the interpretation of the structural history of this area has been stressed (Henderson, in press). Additional samples were collected from the bitumen-impregnated brecciated sandstone on the island of Qeqertarssuaq (see Henderson, 1969b). Poor weather conditions prevented extensive examination of the marine sediments of the north coast of Nûgssuaq, but visits were paid to sedimentary localities on north-east Disko and south Nûgssuaq. At both localities visited on the south coast of Nûgssuaq there is evidence that the sediments were deposited in a deltaic environment.

The area south of Niaqornat, on the north coast of Nûgssuaq, was the subject of a three-week study by P. Philip. Heim (1910) described briefly both picrite and basalt breccia occurring close to a small graphite pit in this area. A large picrite intrusion was later reported to be present in this part of Nûgssuaq, and was shown in a sketch by A. Rosenkrantz (in Birkelund, 1965, plate 49) and was mentioned by Rosenkrantz \& Pulvertaft (1969) and by Henderson (1969a; 1969b), but no detailed study had previously been made of the rocks in question.

In the area studied, a sequence of altered ultrabasic/basic breccias overlies black shales. The breccias are well layered and contain shale beds. No trace was found of any picritic intrusions, and no intrusion was found that would account for the graphite in the old graphite pits.

A brief visit was paid by $T$. Jürgensen to the fossiliferous locality at Marrait kitdlit (Rosenkrantz, 1970) where samples were collected for the purpose of examining and determining the bryozoan fauna.

The writer had the opportunity of studying two areas in detail. At the start of the season work was concentrated north-west of Marrait kangigdtlit, where a pattern of block faulting has resulted in repetitions of the sequence of pillow breccias overlain by subaerial lavas. At the same time, an area just south-east of the Itivdle valley mentioned briefly by Henderson (1969a) was re-examined. The rocks concerned are green, highly altered pillow breccia and not picrite. 
The headland on which the village of Niaqornat is built was investigated further. The rocks are pillow breccias and subaerial lavas and show clear evidence of instability during the early Tertiary volcanism.

\section{Geophysical group}

A seismic party led by P. V. Sharma (Univ. of Copenhagen) undertook seismic refraction investigations along the north coast of Nûgssuaq between Sangmissoq, 3 $\mathrm{km}$ north-west of Tuperssuartâ, at the north-eastern end of the Itivdle valley, and Ikorfat, $28 \mathrm{~km}$ east of Tuperssuartâ. The object of the work was to determine the velocities of the rocks exposed at surface and to determine the depth to basement. 11 profiles were shot, eight for velocity measurements and three for basement depth determinations.

The assigned velocity ranges for rocks outcropping at surface are as follows:

Quaternary sediments flooring the Itivdle valley:

Tertiary basalts at Sangmissoq:

$1800-2300 \mathrm{~m} / \mathrm{s}$

Cretaceous sediments near Tuperssuartâ:

Precambrian gneiss at Ikorfat: $5800-5900 \mathrm{~m} / \mathrm{s}$ $2800-3200 \mathrm{~m} / \mathrm{s}$ $5500-5900 \mathrm{~m} / \mathrm{s}$

High-velocity sediments are found at depth overlying the basement in the area south of Niaqornat. These had a velocity range of $4300-4600 \mathrm{~m} / \mathrm{s}$. Their age is unknown.

Final calculations have still to be made but a preliminary estimate of minimum depth to basement in the area studied based on identification of second-order refraction events is $2600 \mathrm{~m}$.

A programme of sampling for palaeomagnetic investigations at the University of Copenhagen was undertaken on Disko and in parts of Nûgssuaq. The sampling was undertaken by K. Jørgensen, assisted later in the season by C. Mohr, both of whom were assistants on the expedition. 257 samples were collected from ten profiles, corresponding to 82 flows and one sill.

Of the six profiles sampled on Disko, five represented a total sequence of 1350 $m$, i.e. from the oldest olivine-rich flows just above the pillow breccia up to and including the transition sequence to the upper tholeiites. In addition, samples were collected from the telluric-iron-bearing sequence at Asuk.

Four profiles were sampled on Nûgssuaq, three along the north coast and one on the south-west coast, each representing a fault block.

\section{Drilling group}

A programme of shallow-core drilling was carried out using a Craelius Prosper 25 core drill belonging to the Danish Atomic Energy Commission, Risø. This drill provided cores with a diameter of $16 \mathrm{~mm}$.

Source-rock analysis of surface samples collected during 1968 (see Stevens in Henderson, 1969b) indicated the desirability of obtaining fresher material than 
can be collected in the active zone or at the immediate top of the permafrost zone. Some of the extracts obtained during the analyses showed an unusually high content of sulphur and without fresher material it was not possible to elucidate the part played by this. Although two samples were classified as definite source rocks, a further 11 were classified as doubtful to weak source rocks pending the availability of better material.

Moreover, samples of shales collected at or near the surface in 1968 yielded no foraminifera (Hansen, 1970). It was hoped that microfossils might be found in cores taken below the surface.

The drilling party was led by $\mathbf{H}$. Jørgensen. During the whole of the summer the party had to cope with mechanical problems that were difficult to remedy on the spot. In addition, since no shallow-core drilling had previously been attempted in the shales of this area, numerous setbacks were encountered until experience was gained. By the end of the summer, coring was proceeding satisfactorily. The first hole, which was drilled east of the south-western end of the Itivdle valley, was drilled to $13.73 \mathrm{~m}$, with a core recovery of $32 \%$. The last hole was drilled east of Niaqornat to a depth of $16.30 \mathrm{~m}$, and with a core recovery of $39 \%$. Holes were also drilled at Tuperssuartâ and at Pujôrtoq, on the north coast, but little core recovery was obtained. With the experience gained and with freedom from mechanical troubles it should be perfectly feasible to carry out a successful coring programme in the future.

\section{Joint marine geophysical investigations with the Bedford Institute}

At the end of the season the writer and $\mathrm{C}$. Mohr spent three days sailing with the research ship "Hudson", from the Bedford Institute, Dartmouth, Nova Scotia. During this period marine geophysical investigations were undertaken in the area between Hareøen and north of Upernavik and in Umanak Fjord. The results will be given in a joint GGU/Bedford Institute publication, to be prepared in 1972 .

\section{References}

Birkelund, T. 1965: Ammonites from the Upper Cretaceous of West Greenland. Bull. Grønlands geol. Under. 56 (also Meddr Grønland 179, 7), 192 pp.

Drever, H. I. 1958: Geological results of four expeditions to Ubekendt Ejland, West Greenland. Arctic 11, 199-210.

Hald, N. 1971: An investigation of the igneous rocks on Hareøen and western Nûgssuaq, West Greenland. Rapp. Grønlands geol. Unders. 35, 11-13.

Hansen, H. J. 1970: Danian foraminifera from Nûgssuaq, West Greenland. Bull Grønlands geol. Unders. 93 (also Meddr Grønland 193, 2), 132 pp.

Heim, A. 1910: Ưber die Petrographie und Geologie der Umgebungen von Karsuarsuk, Nordseite der Halbinsel Nugsuak, W. Grönland. Meddr Grønland 47, 175-228.

Henderson, G. 1969a: Field work supplementing photogeological interpretation of Nûgssuaq. Rapp. Grønlands geol. Unders. 19, 18-21.

Henderson, G. 1969b: Oil and gas prospects in the Cretaceous-Tertiary basin of West Greenland. Rapp. Grønlands geol. Unders. 22, 63 pp. 
Henderson, G. in press: The geological setting of the West Greenland basin in the Baffin Bay region. Pap. geol. Surv. Can. 71-23.

Pedersen, A. K. 1969: Preliminary notes on the Tertiary lavas of northern Disko. Rapp. Gronlands geol. Unders. 19, 21-24.

Pulvertaft, T. C. R. \& Clarke, D. B. 1966: New mapping on Svartenhuk peninsula. Rapp. Gronlands geol. Unders. 11, 15-17.

Rosenkrantz, A. 1970: Marine Upper Cretaceous and lowermost Tertiary deposits in West Greenland. Bull. geol. Soc. Denmark 19, 406-453.

Rosenkrantz, A. \& Pulvertaft, T. C. R. 1969: Cretaceous-Tertiary stratigraphy and tectonics in northern West Greenland. Mem. Am. Ass. Petrol. Geol. 12, 883-898.

\section{A NEW STATION FOR GROUND TEMPERATURE MEASUREMENTS AT CHRISTIANSHÅB, CENTRAL WEST GREENLAND}

\section{Ole B. Olesen}

In July a further station for ground temperature measurements was established at Christianshåb. This station is the eighth erected in West Greenland as part of the Danish contribution to the UNESCO International Hydrological Decade programme (IHD). The first station was set up at Holsteinsborg in 1964, followed by a second there in 1967, two in Søndre Strømfjord in 1967, and single stations at Jakobshavn 1968, Godhavn 1968 and Egedesminde 1970. Apart from one station in Søndre Strømfjord which was closed in the autumn of 1970, all are in operation.

Two types of station have been constructed, both consisting of a small prefabricated wooden hut in which the measuring apparatus, a wheatstone bridge, is situated (see Olesen, 1968). The stations at Holsteinsborg, Søndre Strømfjord, Jakobshavn and Godhavn are constructed as main stations at the corners of a quadrangle of approximately $250 \times 125 \mathrm{~km}$. Apart from at Holsteinsborg where the shallow depth to bedrock only allows 18 thermistores to be installed, the main stations have 21 thermistores permanently embedded at different levels in the ground near the hut. The remainder are only equipped with 12 thermistores and are referred to as small stations. They are situated within the quadrangle outlined by the main stations. The thermistores are composed of platinum wire of resistivity type, mounted in pertinax tubes for protection: each tube holding three thermistores at different levels. Measurement of the thermistores is made every day around midday by local personnel.

It is intended that the main stations remain at the chosen sites throughout the IHD programme while the smaller ones will be moved periodically so that a maximum number of vegetational environments can be included in the 